\title{
Sprawozdanie z działalności Katedry Teologii Katolickiej Uniwersytetu w Białymstoku w roku akademickim 2014/2015
}

\section{Kadra}

W Katedrze Teologii Katolickiej Uniwersytetu w Białymstoku w minionym roku akademickim 2014/2015 zatrudnionych było trzech pracowników. Dwóch pracowników naukowych na stanowisku adiunkta: ks. dr hab. Andrzej Proniewski (p.o. kierownik KTK), ks. dr Tadeusz Kasabuła oraz ks. mgr lic. Leszek M. Jakoniuk (pracownik administracyjny w sekretariacie KTK).

\section{Działalność dydaktyczna}

Katedra Teologii Katolickiej w roku akademickim 2014/2015 przeprowadziła trzeci (ostatni) semestr Podyplomowych Studiów Katechetyczno-Pedagogicznych. Zatrudniona kadra na studiach podyplomowych wywodziła się z UwB oraz innych ośrodków akademickich z Polski. 10 grudnia 2014 roku na zakończenie wydano 28 świadectw ukończenia studiów podyplomowych.

W ramach działalności dydaktycznej pracownicy naukowi KTK przeprowadzili następujące wykłady:

ks. dr hab. Andrzej Proniewski:

- „Tajemnice wszechświata. Dialog wiary z nauką” (Wydział Biologiczno-Chemiczny UwB oraz Wydział Historyczno-Socjologiczny UwB) 60 godz.;

- „Katecheza i kultura” (studia podyplomowe) 20 godz.; 
- seminarium magisterskie (Wydział Pedagogiki i Psychologii UwB) 100 godz.

\section{ks. dr Tadeusz Kasabuła:}

- „Wybrane zagadnienia kultury Bizancjum” (filologia rosyjska) 30 godz.;

- „Chrześcijańskie korzenie Europy” (kierunek stosunki międzynarodowe) 15 godz.;

- „Korzenie kultury europejskiej” (kierunek kulturoznawstwo) 30 godz.

- „Język w mediach” (filologia rosyjska) 60 godz.

\section{Konferencje naukowe}

Katedra Teologii Katolickiej UwB w okresie sprawozdawczym była organizatorem 5 konferencji naukowych:

- „Klauzula sumienia” (Białystok 11 stycznia 2015);

- „Prawne, medyczne i etyczne aspekty ochrony ludzkiego życia i rodziny" (Białystok 25 marca 2015);

- „Światowe Dni Młodzieży w Polsce - nadzieje i perspektywy” (Białystok 11 kwietnia 2015);

- „Psychologia a formacja ludzka” (Białystok 16 maja 2015);

- „Hermeneutyka biblijna w kształceniu dorosłych” (Białystok,19 maja 2015)

oraz współorganizatorem 2 konferencji:

- „70 lat od przeniesienia Archidiecezjalnego Seminarium Duchownego z Wilna do Białegostoku" (Białystok, 21 maja 2015);

- „(R)ewolucja macierzyństwa” (Białystok 25 maja 2015).

\section{Działalność naukowo-badawcza}

Pracownicy naukowi KTK UwB w ramach działalności naukowo-badawczej opublikowali efekty swojej pracy.

Monografie, rozdziały książek, artykuły

ks. dr hab. Andrzej Proniewski:

- Wiara jako postawa człowieka myślacego w refleksji Benedykta XVI, „Rocznik Teologii Katolickiej”, t. 13/1 (2014), 139-157.

- Gabriele Amorth, Odejdź ode mnie szatanie, Częstochowa 2013, ss. 96, „Rocznik Teologii Katolickiej”, t. 13/2 (2014), 277-279.

- S. Anna Mroczek CSA, Dobrego dnia z Aniołem Stróżem. Myśli na każdy dzień, Częstochowa 2013, ss. 154, „Rocznik Teologii Katolickiej” 13/2 (2014), 281-282. 
- L'ermeneutica del sensus fidei in Joseph Ratzinger, „Studia Koszalińsko-Kołobrzeskie" 21 (2014), 147-155.

- Sakramenty droga życia wiecznego, [w:] M. Chojnacki, J. Morawa, A. A. Napiórkowski (red.), O bogactwach Kościoła, Kraków 2014, 269-284.

\section{Redakcja:}

- „Studia Teologii Dogmatycznej”, 2015, t. 1.

- „Rocznik Teologii Katolickiej”, 2014, t. 13/1.

- „Rocznik Teologii Katolickiej”, 2014 t. 13/2.

\section{ks. dr Tadeusz Kasabuła}

- Archidiecezja Białostocka, [w:] Archidiecezja Białostocka 2014, red. J. Jabłoński i in., Białystok 2014, s. 53-67.

- Współred. Archidiecezja Białostocka 2014, red. J. Jabłoński i in., Białystok 2014 (m.in. autorstwo zarysów dziejów 114 parafii Archidiecezji Białostockiej), ss. 607.

- Diecezja wileńska. Studia i szkice, red. T. Kasabuła, A. Szot, Białystok 2014, ss. 504.

- Kościelna dziatalność Izabeli Branickiej w Biatymstoku, [w:] Izabela $z$ Poniatowskich Branicka. Życie i dziatalność publiczna, red. C. Kuklo, Białystok 2014, s. 65-74.

- „Ten dąb tak stary w ziemię wróst”. Kazanie wygtoszone w 96 rocznicę odzyskania przez Polskę niepodlegtości, katedra biatostocka-11 XI 2014 r., ,Wiadomości Kościelne Archidiecezji Białostockiej”, 42 (2014), nr 4, s. 165-168.

- Wileńska Archidiecezja, [w:] Encyklopedia Katolicka, t. 20, Lublin 2014, kol. 593-608 (współautor S. Brzozecki).

- Z życia i działalności naukowo-dydaktycznej Księdza Profesora Tadeusza Krahela, [w:] Diecezja wileńska. Studia i szkice, red. T. Kasabuła, A. Szot, Białystok 2014, s. 15-17.

- Proboszczowie parafii Turośń Kościelna w latach 1969-2015, [w:] Parafia w Turośni Kościelnej 1515-2015, red. A. Szot, M. Wróbel, Białystok - Turośń Kościelna 2015, s. 383-397.

- Pratatury i kanonie de gremio Kapituty Katedralnej Wileńskiej w okresie przedrozbiorowym, „Rocznik Teologii Katolickiej”, t. 15/1 (2016) [w druku].

- Wartość źódtowa akt wizytacji diecezji wileńskiej z drugiej połowy XVIII wieku, ,Studia Teologiczne. Białystok - Drohiczyn - Łomża", 33 (2015) [w druku].

- Schematyzmy diecezjalne w ich historycznym rozwoju, „Archiva Ecclesiastica", 8 (2015) [w druku]. 
- Parafia Choroszcz w okresie I wojny światowej, „Wiadomości Kościelne Archidiecezji Białostockiej”, 43 (2015), nr 2 [w druku].

Katedra Teologii Katolickiej UwB w roku sprawozdawczym podejmowała próby otrzymania dofinansowania projektu badawczego: System wartości studentów z trzech głównych ośrodków akademickich miasta Białegostoku z perspektywy teologii kultury. OPUS 6- Narodowe Centrum Nauki. W wyniku konkursu projekt nie został zakwalifikowany do sfinansowania.

\section{Udział w konferencjach, zjazdach naukowych i wydarzeniach kulturalno-naukowych, referaty}

W roku akademickim 2014/2015 pracownicy naukowi oprócz uczestnictwa w wydarzeniach organizowanych lub współorganizowanych przez KTK wzięli udział w sympozjach i zjazdach:

\section{ks. dr hab. Andrzej Proniewski:}

- Sesja naukowa dla kapłanów z diecezji ełckiej: „Współczesne zagadnienia chrystologiczne" (8.11.2014 - Wigry);

- Warsztaty dla kapłanów: „Nowa ewangelizacja - między teorią a praktyką" (10-11.02.2015 - Białystok). Organizator;

- Ogólnopolska Konferencja Naukowa: „Skarby Kościoła” (24.02.2015 - Wydział Teologiczny UP JPII), Kraków. Referat: „Sakramenty - drogą życia wiecznego";

- X Międzynarodowa Konferencja Naukowo-Szkoleniowa: „Życiodajna śmierć - pamięci Elizabeth Kübler-Ross" (23-26.04.2015 - Białystok);

- Sesja naukowa środowiskowa dla bibliotekarzy: „Dedykacje rękopiśmiennicze z lat 1901-1939 w księgozbiorze abp. Romualda Jałbrzykowskiego" (14.05.2015);

- Konferencja naukowa: „Prawne, kryminologiczne i medyczne aspekty wykluczenia społecznego" (11-14.05.2015 - Supraśl). Udział w dyskusji panelowej nt.: „Zapobieganie wykluczeniu społecznemu w ujęciu praktycznym";

- 51. Konferencja Rektorów Wyższych Seminariów Duchownych Diecezjalnych i Zakonnych: „Formacja pastoralna do kapłaństwa” (07-10.09.2015 - Olsztyn);

- XI Zjazd Stowarzyszenia Teologów Fundamentalnych w Polsce: „Islam. Apologia i dialog” (16-18.09.2015 - Rzeszów). 
- Konferencja naukowa Towarzystwa Teologów Dogmatyków: „Sakrament małżeństwa we współczesnej debacie teologicznej” (21-23.09.2015 - Bydgoszcz).

\section{Referaty:}

- Stowarzyszenie Katolickie Lekarzy Katolickich: „Teologia w ekologii w świetle encykliki Papieża Franciszka Laudato si" (13.09.2015 - Białystok).

\section{ks. dr Tadeusz Kasabuła}

- Wernisaż wystawy: „XX-wieczne tkaniny w zbiorach Muzeum Archidiecezjalnego w Białymstoku" - organizacja wystawy Sprawozdania (12.11.2014 - Białystok).

- Sesja naukowa poświęcona promocji książki Diecezja Wileńska. Studia i szkice - prezentacja Autora i omówienie publikacji (24.01.2015 - Wilno).

- Sesja naukowa „Ksiądz Stanisław Suchowolec 1958-1989)” współorganizacja (30.01.2015 - Białystok).

- Warsztaty duszpasterskie „Współczesne wyzwania Nowej Ewangelizacji” - współorganizacja, głos w dyskusji (10-11.02.2015 - Białystok).

- Wernisaż wystawy i sesja naukowa poświęcone osobie i dziełu bł. ks. Michała Sopoćki pt. „W cieniu krzyża wychowują się dusze promienne" - organizacja (17.02.2015 - Białystok).

- Wernisaż wystawy „Znane i nieznane” - współorganizacja wystawy (09.04.2015 - Białystok).

- Otwarcie i wernisaż wystawy „Podlaski Nikifor” - malarstwo księdza Henryka Błaszczyka” - organizacja (22.04.2015 - Białystok).

- „Noc Muzeów” w Archiwum i Muzeum Archidiecezjalnym w Białymstoku - organizacja (16-17.05.2015 - Białystok).

- Prezentacja wystawy: ,70 lat Seminarium Duchownego w Białymstoku" w Archiwum i Muzeum Archidiecezjalnym w Białymstoku w ramach Podlaskich Festiwalu Nauki i Sztuki - organizacja (19.05.2015 - Białystok).

- Sesja naukowa i wernisaż wystawy pt. „8 maja $1945 \ldots$ rodzi się nowe" - organizacja (21.05.2015 - Białystok).

- Sesja naukowa pt.: „Jan Długosz (1415-1480). Duchowny - dziejopisarz - mąż stanu” - współorganizacja, referat: „Chrzest i chrystianizacja Litwinów według Jana Długosza” (17.06.2015 - Białystok). 
- Sesja popularnonaukowa pt.: „Choroszcz w czasie I wojny światowej” - referat: „Parafia rzymskokatolicka w Choroszczy w latach 1914-1919" (25.08.2015 - Choroszcz).

- Otwarcie i wernisaż wystawy: „Co się komu w duszy gra - muzyka świata w polskim domu" - organizacja wystawy (16.09.2015 - Białystok).

- Otwarcie i wernisaż wystawy: „Ona zetrze głowę Twoją - Rycerstwo Niepokalanej" - współorganizacja wystawy (30.09.2015 - Białystok).

\section{Wydawnictwo}

Nakładem Wydawnictwa Uniwersytetu w Białymstoku w ramach działalności KTK ukazały się następujące pozycje:

- „Rocznik Teologii Katolickiej”, 2014, t. 13/1 (8 punktów)

- „Rocznik Teologii Katolickiej”, 2014, t. 13/2 (8 punktów)

- „Studia Teologii Dogmatycznej”, Człowiek istota (po)znana, Białystok 2015, t.1 